Article

\title{
Social Housing as an Experimental Approach to the Sustainable Regeneration of Historic City Centers: An Ongoing Study of Sassari City, Italy
}

\author{
Nađa Beretić * $*$ and Valentina Talu $(\mathbb{D}$ \\ Department of Architecture and Urban Planning, University of Sassari, 07041 Alghero, SS, Italy; vtalu@uniss.it \\ * Correspondence: nberetic@uniss.it; Tel.: +39-3664571049
}

Received: 28 April 2020; Accepted: 2 June 2020; Published: 4 June 2020

\begin{abstract}
The urban development in the 21st century builds upon sustainable urban redevelopment. In this paper, we use urban regeneration as a strategic intervention that reverses social and physical decline through an integrated approach. We argued that social housing is an important strategic intervention of urban regeneration. Unlike many European countries, social housing in Italy has remained an experimental field that urgently needs new models, and urban planning tools and techniques. We presented guidelines for an experimental social housing model. We focus on abandoned buildings and spaces, social issues, and services, with the goal of contributing to urban welfare in the old town center of Sassari City. This approach goes well beyond efforts to put uninhabited or degraded land and buildings to new uses. A model is an integrated tool that is capable of triggering and guiding the processes of social innovation, inclusion, cultural promotion, and economic development. It grounds on the collaborative use of spaces that stimulate a new culture of living together: collaborative living. This paper is based on the results of an ongoing research project, which involves the local University and the Municipality. More research is needed to enclose the model.
\end{abstract}

Keywords: urban regeneration; social housing; historical center; planning tools; collaborative community; Italy; Sassari; sustainable development

\section{Introduction}

\subsection{Sustainable Urban Regeneration and Mediterranean Cities}

The urban regeneration concept appeared after World War II and is aimed at the physical restructuring of the urban fabric. This concept has evolved over time, and contemporary urban regeneration is focused on sustainability and the balance between economic, social, and environmental values [1-3]. Because of the social features of urban renewal and public housing renovation in the mid-1970s [1,2], social sustainability has dominated urban regeneration [4]. Cohesion politics and housing policy of marginalized groups have become agents of sustainable urban development $[5,6]$, which has been promoted through an integrated approach [4-9]. The integral approach of cohesion policies establishes the necessary connection among the principal political concerns of the wider area. Otherwise, this practice may lead to community break-ups, the loss of the original relationships, and increased isolation [4,10-12]. European cities have demonstrated a certain capability of achieving significant changes through experimental social innovation. Nevertheless, integrated politics and stronger support from higher levels of governance are required to potentiate sustainable places [4] and replicate models [5]. Even though much literature examines the concepts of urban regeneration, social sustainability, and cohesion policies, this research field remains undeveloped $[4,12,13]$. In this paper, we use urban regeneration as a strategic intervention that reverses social and physical decline through an integrated approach. 
Urban dynamics are negatively influenced by the abandonment of lands and buildings, environmental degradation, unemployment, and deterioration in social life $[7,14]$. All issues of urban regeneration have emerged from the complexity of urban dynamics [3,6,15]. In Mediterranean cities, urban complexity may be addressed to place-specific contexts and multidimensional characters that have developed over multiple centuries [6]. Specific to the context, the poor physical and environmental settings of the wider area are, indeed, the main issue on which urban regeneration must respond $[6,10]$. Despite having a fundamental role in an urban regeneration process, the approach to a place-specific context has been misinterpreted many times.

Previous studies that have examined changes in the urban structure have provided the consequences of urban transformation instead of trying to understand the causes of the decaying conditions. Consequently, an extremely complex process was tackled, and the problems, objectives, and visions were mistakenly interpreted [7,15]. In Europe, the most frequent challenges of research on urban decline are negative social trends and the considerable influence of economic factors. These factors are often investigated in isolation $[7,15]$. In order to avoid isolated research of factors, we conceived the development model that uses an integral approach.

The multidimensional character of urban regeneration requires planning (plans, strategies, and policies) on various administrative levels and negotiation between different public, private, and civic interests to prioritize the objectives $[6,10,14]$.

Mediterranean cities are often subject to the protection of cultural monuments due to their rich history. However, these are central to urban regeneration. Consequently, the conservation of architectural heritage and historic cores are underlining goals in the regeneration process. However, the true values of Mediterranean cities frequently remain neglected due to inappropriate planning and governance.

Founded between the 1960s and 1980s, institutional structures and urban policies have become outdated and insufficient to satisfy the current needs [6,16]. At the same time, modernization has influenced governing bodies and policies, yet Mediterranean practices "bear no relevance to modern conceptualizations of planning" (see [6], p. 5). The problems with Mediterranean practices include disassociated land-use planning from other instruments (for example, economic policies), partially selective implementation, single-sector-related operations, or wide-scale development plans. All these planning practices are difficult to implement [6] while being problematic from the aspect of sustainability.

\subsection{Social Housing in Italy}

Social housing in Italy is undergoing an economic crisis, societal evolution, and delayed or absent public housing policies [17]. Unlike many European countries, Italy did not go through a "housing revolution" during the 1970s and 1980s [18,19]. In most European Union (EU) member states, the decentralization of social housing policies has changed the relationship between the State and social housing providers [20]. The development of integrated models prevented social-spatial segregation and ensured social mix and cohesion, which are a key objective of housing provision. The diversity of housing tenures and new models of shared ownership also assured various possibilities of accessing the social housing market [18-21]. In Italy, the severe housing deprivation rate remains very high at $11.1 \%$, compared with the EU average of $5.6 \%$ for the year 2017 [20]. Only $4 \%$ of the Italian population has access to housing with subsidized rent. Compared with the $27 \mathrm{EU}$ member states, this data place social housing in Italy among the worst-ranked; the last is Greece, followed by Portugal, Spain, and Italy $[18,21]$. Likewise, the recent development of housing policy is insufficient if compared with Germany and Belgium, with whom Italy shares a generalist approach to social housing: "one that allocates housing to households falling under a certain income ceiling" (see [21], p. 15). Dissimilar to these countries, urban renewal programs are a priority issue rather than routine in social housing projects. Housing providers have recently recognized the need for domiciliary care and neighborhood and support services [21]. 
In spite of having 700,000 homes across the country managed by the public housing sector, the stock is insufficient [21]. The severe underfunding of the public housing sector causes a low level of new supply and problematic maintenance and management of the stock [20]. The shortage of affordable rental housing is a common problem for most major cities in EU countries. In Italy, this problem is one of the biggest issues, regardless of city size [20-22]. Affordable housing became problematic due to the profound changes that affected housing supply and demand over the last fifty years [22]. In the period between 1977 and 2006, housing demand demonstrated a sharp decrease in rental housing at the national level. The number of tenant families had halved (going from $40 \%$ to $20 \%$ ), and included tenant families that lived in public housing [23]. Regional variations are significant, e.g., islands have the lowest value of tenant families at $14 \%[19,24]$. During the 1960s, incomes were adequate to sustain housing needs, but purchasing power has declined over time. The inadequate income levels have been sustained by the massive use of credits (and debts), resulting in the possibilities of property investments. However, the prolonged decline of income has barred applications for new credit. In other words, moderate inflation and the absence of income growth, together with an increase in housing prices, has precipitated the access to the housing market [22]. Response from the state remained low, where housing and welfare coverage stayed minimal, even though housing problems are affecting an ever-increasing share of the population. The poorest families are most concerned, but the middle class is also affected $[17,22,25]$. The problem of affordable housing represents an urgent matter as it affects beneficiaries (people in need of affordable housing) and various stakeholders, namely, institutions, ethical investors (banking foundations, ethical finance operators), and real estate market operators [26].

Social housing aims to meet the housing demand of those who cannot access the free market, but who are still in a position to sustain the rent with controlled prices or to buy accommodation at a contracted price [27]. In Italy, it is not possible to use the term "social housing" with a precise reference to the law. Instead, we can frame three national practices of housing that address different beneficiaries, stakeholders, and funds: (a) private investments in the housing sector, (b) the traditional public housing sector or popular housing (ERP), and (c) the social housing sector (ERS) that represents a more recent and upgraded practice of the ERP, private housing investments operate by free-market conditions. ERP exclusively supplies the disadvantaged layers of society, and it is fully funded from the public budget, with nonrefundable grants. ERS provides housing for all those who cannot find an adequate answer to their housing needs either in the ERP or on the free market. The financial resources for its realization can be private or a partnership of public-private, and this includes the possibility of establishing specific real estate funds. Allowing the integrated design of buildings, services, and participative activities, ERS constitutes an extension of ERP interventions. Both ERS and ERP construct the social housing sector in Italy. Social housing targets an expansive "gray area" [28], which identifies possible beneficiaries of ERS. The Housing Plan of 2018 lists seven types of "gray areas" as legible candidates: low-income households (including single-parent or single-income families), low-income young couples, the elderly in disadvantaged social and economic conditions, offsite students, those subject to executive release procedures, others in possession of the requisites by law, and regular low-income immigrants residing or living in Italy for a long period [29].

Considering the national situation, social housing has remained an experimental field [17-19]. Policies and new models require interpretation to respond to the misalignment between the price of social housing and the purchasing power-affordable housing. This new social housing model must counteract housing discomfort by increasing urban welfare. An integral intervention of social housing should challenge the conception of a house due to contemporary societal needs. This supports the conversion of the concept of a house as real estate into a house as a "flexible environment" that is able to satisfy changing needs over time. 


\subsection{Context-Specific Issues and Opportunities: City of Sassari}

This research analyzed the historical town center of Sassari City (Italy) and the possibilities of regenerating its poor physical and environmental settings. Despite its high historical and cultural value, the old town center is considered as a marginal, deprived urban area because of socio-spatial segregation. Although the presence of dilapidated buildings and spaces are obvious to an observer, adequate documentation regarding those buildings and spaces is missing. Accordingly, the first research challenge was to produce evidence of dilapidated spaces and buildings with quantitative and qualitative data. It aims to picture the nature of the context-specific abandonment phenomena.

Addressing the context-specific needs, we aim to find the possibilities of increasing social housing stock. Changes in housing policy have opened up the possibility of supporting this decision. The most recent Ministerial Decree (24 February 2015) [30] established that the public housing sector may proceed with real estate alienation aimed at the rational and economic management of assets. This is in accordance with regional programs aimed at satisfying housing needs. The funds are increasingly moving towards the outsourcing of real estate assets to be included in the social housing regime. These are signs of growing sensitivity towards the issues of land use and the recovery of existing real estate assets. The Regional Investment Fund for Social Housing has demonstrated interest in taking action in northern Sardinia, and in the city of Sassari. An intention towards concrete investment opportunities exists, but neither project nor vision is present.

For all these reasons, we recognize the opportunity to experiment with social housing, seeing it as an integrated instrument for positive changes of the urban tissue in decay. In this paper, we propose guidelines for the social housing model, which has emerged from spatial issues of buildings and spaces. We focus on adequate services and open public spaces that constitute the guidelines, with the goal of contributing to urban welfare in the old town center. This approach goes well beyond efforts to put uninhabited or degraded land and buildings to new uses. The flexible social housing model presented here is an integrated tool, capable of triggering and guiding the processes of social innovation, inclusion, cultural promotion, and economic development.

\section{Materials, Methods, and Study Area}

\subsection{Study Area}

This paper is based on the results of ongoing research projects that investigate the old town center of Sassari City. The research project "Urban regeneration and social energies" is led by the Department of Architecture, Design, and Urban Planning of Alghero, University of Sassari (Italy), while the Municipality of Sassari is contributing to this project.

The City of Sassari is the second biggest in the region, located in the north of Sardinia Island (Figure 1).

\subsection{Materials and Methods}

The methodological process can be divided into five related phases. We chose a flexible and modifiable methodological approach, as these phases identified different obstacles during the initial phases of surveying and data processing.

First, the desk research was based on secondary analysis and literature reviews. It aimed to define and describe fundamental concepts, which refer to social housing as a tool for sustainable urban regeneration. The desk research also includes socio-demographic analyses of the local context, used later to define the community profile.

Second, we investigated the cartographic database (vector and raster maps). At the very beginning, we noticed a lack of adequate and updated cartography. We needed to digitize some cartography or its codification systems in the first place. Data also lacked homogeneous quality; that is, it had a misaligned geometry or georeferencing system. The databases' information was frequently absent. All these problems implied a deficiency of testing and updating of the information layers. In order 
to create an accurate database that will serve for the future use of the municipal sector for urbanism, we formulated our own database. The database was adapted for the use in Geographical Information System (GIS) software. The GIS structure was organized into five groups of attributes: property and registry information, description of the single object, cadastral data, the classification codes indicated in the detailed plan of the historical center (DP), and DP documentation (hyperlinks with projects and materials about the singular building, which are specified by the DP). The GIS was conceived as a future pragmatic and operative planning instrument. It is considered as the most suitable tool because it guarantees continuous integration, modification, and data update, which are associated with the georeferenced objects.

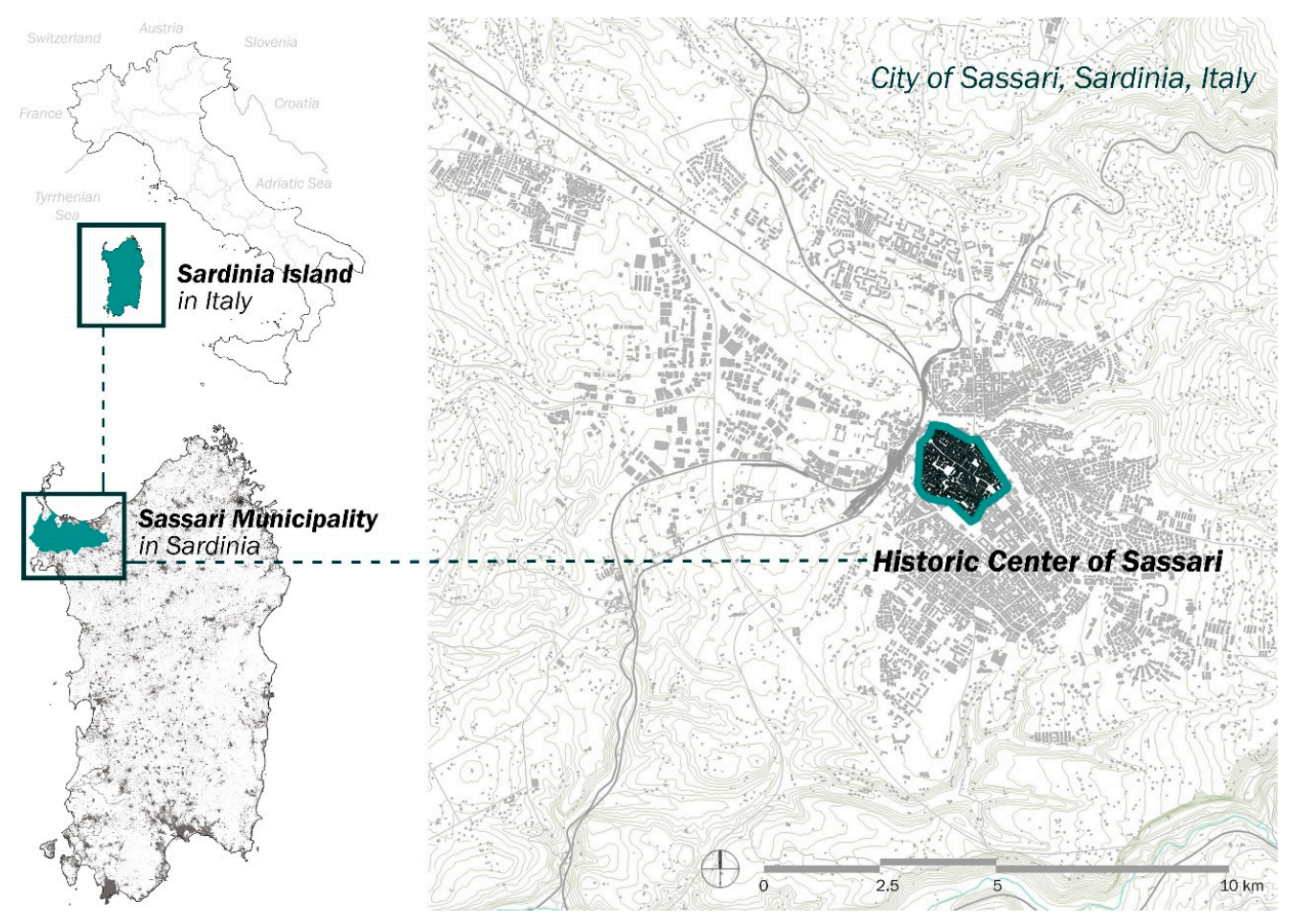

Figure 1. Position of Sassari City, Sardinia, Italy (source: authors).

Third, the surveying followed the preliminary GIS structure. The data collected during the spatial assessments was merged with existing plans and other documentation. The GIS database draws cumulative information about field surveying and multiple layers of existing documentation, including "DataBase GeoTopografico (DBMP)", digital orthophoto "HiRes", digital orthophoto "Pictometry"M", areal photogrammetry "Pictometry ${ }^{\mathrm{TM}}$ ", municipal numerical technical cartography, architectonical constraints "MIBACT", DP, and cadastral maps. Once the GIS database was completed, we shared it with the technical section of the sector for urbanism.

Fourth, we processed and analyzed the dataset. Accumulative findings of all four stages of the research served to produce the fact sheet.

Based on cumulative outcomes, we planned the experimental model of social housing as the final stage of our research project. We proposed a set of guidelines to develop the regeneration scenarios in the context of the old historical center of Sassari. The guidelines are based on the condition of the dilapidated buildings and spaces in the historic center, and they are constrained by the preservation of building heritage. The guidelines suggest ways to regenerate those spaces and to increase urban welfare. Physical spaces were the starting point of the research but in the function of serving the people, namely, local communities and potential beneficiaries of social housing and supporting staff.

Taking everything into account, the guidelines aim to provide theoretical directions using urban plans, and the results of the location analysis. The integral social housing intervention is an experimental 
model, and, as such, it will be complete only once all stages of the project are finished. The next phases have to integrate governance aspects, legislative and administrative mechanisms, as well as economic feasibility. Thus, in this paper, we define components of the model, relationships amongst them, and present the results of the first stage: guidelines that have emerged from the local context (Figure 2).

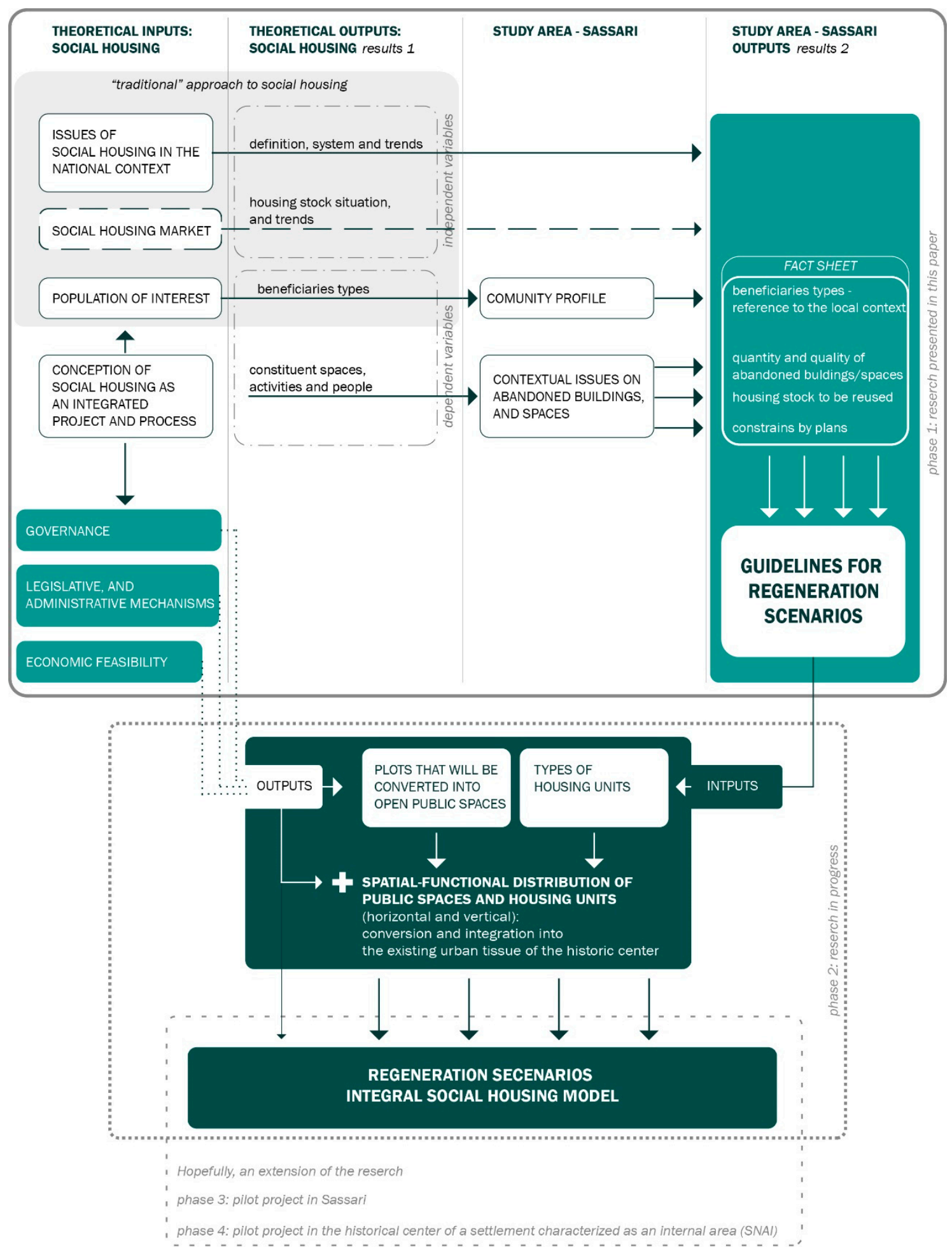

Figure 2. Research stages and components of the social housing model (source: authors). 


\section{Urban Decay and Housing Discomfort in the Historical Center of the Sassari City: A Fact Sheet}

In the historical center of Sassari, the biggest issue is the contradiction between high historical and cultural value and high socio-spatial segregation. The segregation is represented through numerous features and amongst these, the main ones are

- A gradual and progressive loss of population;

- Simultaneously concentrated depopulation in some areas and, in contrast, overcrowded areas in the other parts of the historical center;

- The presence of a significant number of immigrants in the center and its historic districts;

- Scarce provision of local services in contrast to numerous prestigious buildings and relevant public services;

- Historical and cultural identity and values;

- Physical decay and high number of dispersed buildings and public or semi-public spaces in a state of degradation, partial or total;

- Numerous unoccupied buildings;

- Poor local accessibility.

We aim at an integral social housing model to address all these contextual problems and values. To design the model, we started from the definition of the fact sheet. The results presented in the fact sheet comprise information about abandoned, specifically dilapidated buildings and community profiles. Information collected in the fact sheet permitted the development of the guidelines for the regeneration scenarios and the social housing model conception. The guidelines are discussed in the next section.

\subsection{Dilapidated Buildings of the Historic Center of the Sassari City}

The historical center of Sassari is divided into five districts: Santa Caterina, San Sisto, San Donato, San Nicola, and Sant'Apollinare. If we compare the data of the Italian Statistical Institute (ISTAT) for the years 2001 and 2011, the number of unoccupied buildings in the historical center has grown from 23\% to 29\% [31]. The Municipal Urban Plan states that the presence of numerous dilapidated buildings has caused this condition. In particular, a mediocre or dilapidated conservation status marks approximately $62 \%$ of the buildings in the historic center [32]. Buildings in decaying or declining conditions are found predominantly in the northern area of the historical center. The district San Donato faces the most dramatic situation, having about $40 \%$ of housing stock described as inadequate for living, and $8 \%$ of the stock of dilapidated buildings [32]. A slightly lower rate of decaying conditions, yet still very high, marks the districts of San Caterina and San Nicola, located in the southeastern part of the historic center. Paradoxical to this situation, the highest number of buildings with the greatest architectural value is located in these districts.

We have identified, mapped, and described 157 abandoned buildings in decaying conditions. The distribution of the buildings is sparse across all five districts. To classify the buildings by the state of conservation, we used the terminology of the DP [33] and the mapping method we created. The state of conservation is defined by four categories defined by DP: dilapidated, mediocre, decent, and good. The buildings classified as dilapidated are in a state of visible abandonment, presumably not occupied for many years. Their roofs have collapsed totally or partially, the degradation of doors and windows is advanced, whilst walls and plaster works demonstrate the decaying condition. Dilapidated buildings are of our primary interest since they need the most immediate intervention. In the absence of substantive interventions over the next five years, mediocre buildings will be abandoned and at risk of a quick transition to dilapidated buildings. We considered decent and good conditioned buildings as one category due to their secondary importance to this research. We described these buildings only to build a more articulated and broader fact sheet as well as to extend the intervention in future iterations 
of this project. Buildings in good and decent conditions are unoccupied or abandoned, and they are mostly located near one or more buildings in a ruined condition.

Figure 3 summarizes the crucial findings of abandoned buildings in the historic center of Sassari City. Dilapidated buildings make $60 \%$ of building stock: 75 out of all 157 are abandoned. A mediocre condition describes $31 \%$ of the buildings. Only $9 \%$ of buildings are in decent condition, and only a single building has been classified in good condition. In spite of dispersed distribution across all districts, a prevalent number of abandoned (31\%) and dilapidated buildings (35\%) are located within the district of San Donato. In the San Donato district, $7.6 \%$ out of a total of 645 buildings are abandoned, and $5.1 \%$ of buildings have dilapidated conservation status. Compared with the DP data, these results demonstrate more problematic urban decay and indicate a significantly higher percentage of abandoned and dilapidated buildings. The number of abandoned and dilapidated buildings is somewhat smaller in the San Nicola and Sant'Apollinare districts. In the remaining two districts, the surveyed buildings are presented only sporadically. However, spatial distribution is not a principal criterion for this research. We were focused on the state of conservation because it is a condition of the possibilities of intervention on the buildings.

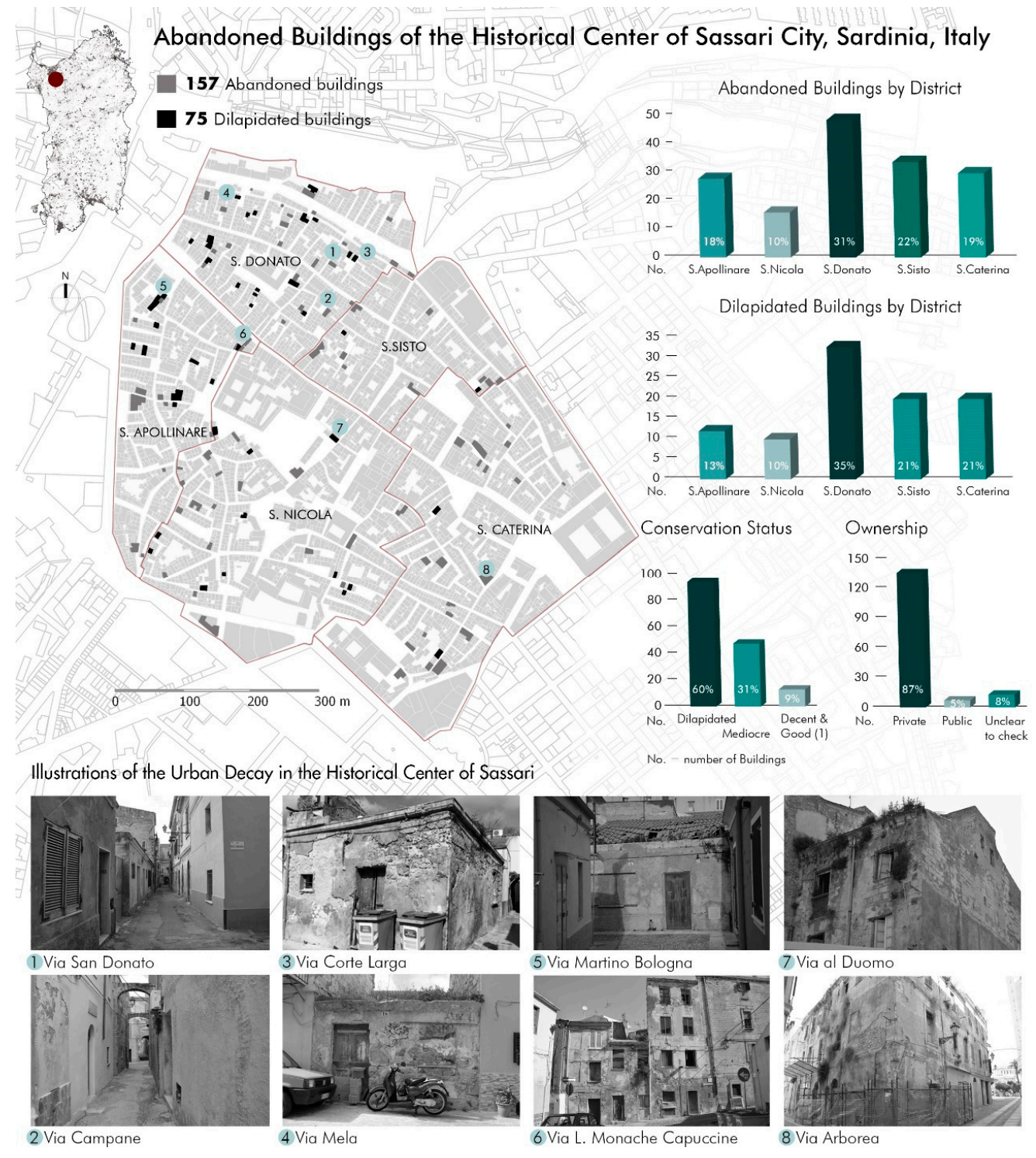

Figure 3. Abandoned buildings in the historic center of Sassari City (source: authors). 
The most dilapidated buildings are in private ownership. A majority are privately co-owned buildings $(87 \%)$, and that causes additional complexities in understanding the ownership patterns. Privately co-owned buildings have numerous owners, sometimes even more than ten. Local governance and housing investment agencies own a small number of buildings. These results are extremely valuable as input for the conceptions of administrative and legislative mechanisms and future governance scenarios. In particular, this means that the new models will have to motivate many co-owners and other stakeholders. In order to substitute or at least supplement the traditional way of financing from the public budget, the innovative social housing models have to be attractive and economically convenient for private co-owners.

\subsection{Community Profile of the Historic Center}

Three phenomena describe the socio-demographic context of the historic center: (a) depopulation, (b) unplanned overcrowding housing conditions, and (c) a high percentage of an elderly population. The historic center has 8218 inhabitants, which makes $6.5 \%$ of the total population in the municipality. The comparison of population data shows a growing trend in the municipality of Sassari, and a decrease in the historic center (Figure 4). The reduction of population in the historic center was initiated by the voluntary relocation of the people who were seeking better living conditions. These buildings are now abandoned, while the decay continues. All of this results in a situation where the buildings are becoming more and more unattractive to new inhabitants.

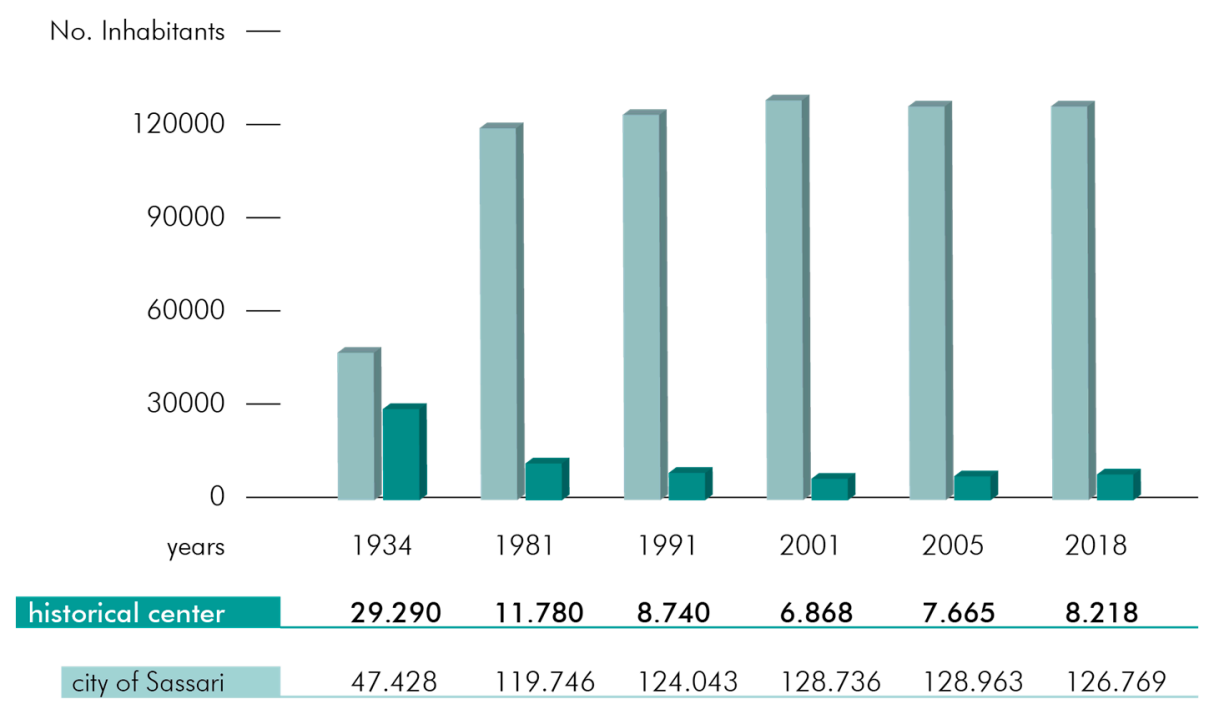

Figure 4. Comparison of the population data: the historical center and Sassari City (authors' elaboration of Italian Statistical Institute (ISTAT) and Municipal Data Processing Center of Sassari (CED) data [31,34]).

Arrivals of new inhabitants insufficiently compensate for depopulation phenomena. New inhabitants are stimulated by the low rental prices and timid gentrification process [35], populating the historic center with an uneven distribution. Compared to the total municipal area, the percentage of the population with foreign origins is the highest in the historic center. Residents with foreign origin make $20 \%$ of the total residents, and most of them reside in the San Donato district (Table 1).

The immigrant population in the historic center predominantly originates from Senegal, Romania, Bangladesh, and Nigeria [34]. These people tend to adapt to a poor housing environment due to a lack of means to upgrade their living conditions. They share small housing units for economically viable reasons, which leads to overcrowding situations and the degradation of buildings. The overcrowded accommodations in the historic center make $27.1 \%$ of the total housing stock. This percentage is higher than the average in the city $(19.6 \%)$. Also, the average surface of the apartments in the historic center $\left(59.2 \mathrm{~m}^{2}\right)$ is below the standard of the city $\left(75.3 \mathrm{~m}^{2}\right)$ [34,35]. The crowding matrix for the year 2005 shows 
that $25.7 \%$ of the residents live in conditions of serious housing discomfort, using the information of the size of occupied accommodation. Uncomfortable conditions are present in 19\% of accommodations, and $25.5 \%$ of the conditions are below standard [34,35].

Table 1. Distribution of residents with foreign origin in the historic center of Sassari (Authors' elaboration of CED data from April 2018 [34]).

\begin{tabular}{|c|c|c|c|c|c|c|c|c|}
\hline \multirow[b]{2}{*}{ Districts } & \multicolumn{2}{|c|}{ Inhabitants Total of HC } & \multicolumn{3}{|c|}{ Italian Origin $($ No. 6563$)=80 \%$} & \multicolumn{3}{|c|}{ Foreign Origin $($ No. 1655$)=20 \%$} \\
\hline & $>$ No. ${ }^{1}$ & $>\% \mathrm{HC}$ & $>$ No. & $>\% \mathrm{HC}$ & $>\% \mathrm{D}$ & $>$ No. & $>\% \mathrm{HC}$ & $>\% \mathrm{D}$ \\
\hline S. Nicola & 2120 & $26 \%$ & 1821 & $28 \%$ & $86 \%$ & 299 & $18 \%$ & $14 \%$ \\
\hline S. Donato & 2069 & $25 \%$ & 1553 & $23 \%$ & $74 \%$ & 516 & $31 \%$ & $26 \%$ \\
\hline S. Caterina & 1619 & $20 \%$ & 1317 & $20 \%$ & $81 \%$ & 302 & $18 \%$ & $19 \%$ \\
\hline S. Apollinare & 1288 & $16 \%$ & 1038 & $16 \%$ & $80 \%$ & 250 & $15 \%$ & $20 \%$ \\
\hline S. Sisto & 1122 & $13 \%$ & 834 & $13 \%$ & $74 \%$ & 288 & $18 \%$ & $26 \%$ \\
\hline
\end{tabular}

Lastly, the age structure of the population displays $15.3 \%$ of people aged over 65 years (Table 2). The elderly index calculated for the historical center of Sassari is 127 . The elderly index is a statistical unit, which measures the relationship of the population below 14 and over 65 years per 100 young people. Values over 100 indicate an increased presence of elderly people.

Table 2. Age structure of the population in the historic center of Sassari (authors' elaboration of CED data from April 2018 [34]).

\begin{tabular}{cc}
\hline Age & No. Inhabitants of the Historic Center \\
\hline $0-4$ & 289 \\
$5-9$ & 360 \\
$10-14$ & 343 \\
$15-19$ & 370 \\
$20-29$ & 911 \\
$30-39$ & 1238 \\
$40-49$ & 1562 \\
$50-59$ & 1399 \\
$60-64$ & 486 \\
$65-69$ & 401 \\
$70-79$ & 494 \\
$80-89$ & 305 \\
$90-100$ & 59 \\
$>100$ & 1 \\
\hline
\end{tabular}

\section{Guidelines for the Social Housing Intervention in the Historical Centre of Sassari City}

A project of social housing cannot be a solitary instrument for activating and rehabilitating social resources in the target area. It is not even a sufficient tool for the recovery of the decaying urban fabric. Social housing intervention is a process that requires specific organizational and policy conditions that cannot be taken for granted [10]. Likewise, social housing intervention on the existing building heritage may penalize economic sustainability due to the excessive costs of restructuring works. These works usually exceed the costs of new construction. To make reconstruction feasible, we need an intelligent investment approach. For example, if the reconstruction is a priority (in cases of protected buildings and areas), we need to find economically viable routes of reconstruction work. New sustainable materials and modern construction techniques could reduce recovery costs, while innovative forms of collaborative construction, such as regulated self-construction, opens up a new field in the experimentation of economic aspects. In this paper, we focused on the guidelines that discuss the social-spatial aspect of social housing. Firstly, we suggested a social housing project as a process. We identified the requirements and dynamics of such intervention. Secondly, we proposed social housing as an integrated project that comprises housing facilities and nonresidential spaces 
and services. We divided nonresidential spaces into three categories: open spaces, collective spaces and activities, and local urban services. This categorization includes both the concept of social housing and the specificities of the local context. The concept of social housing requires the designing of collective spaces and activities. Local services are the subject of social housing intervention, as the newly formed community has to integrate with the scarce local services in an existing neighborhood. Open spaces are indicated as a component of the social housing intervention due to the local conditions. The historic center of Sassari has a dense urban structure, and open spaces are scarce (if we exclude the streets). On the other hand, DP allows land-use change where some buildings are meant for demolition. We used this opportunity to upgrade the public space network.

\subsection{Social Housing is an Integral Project and Process}

Social housing aims to provide good quality in a residential context. It can simultaneously improve the built environment and social fabrics, contributing to a further increase in the public congregation, activity, social interaction, and cohesion between citizens [36]. When conceived as a process, the social housing intervention is supposed to assemble active participation and experimentation with new forms of living in the project design. Social housing intervention that is designed as a process represents a "project of the community" $[10,37]$. The community does not only include people who are beneficiaries of the social housing intervention, but all actively included inhabitants. The design strategy of social innovation targets a self-sufficient community that is resilient to external threats and problems, open, and inclusive [37]. It does not require new skills or methods in urban design but rather a co-design with the inhabitants of the community. This project must trigger and support social change. It has to be a guided process that investigates the forms of living and sense-making [37]. In that way, the social housing intervention would extend to the management and monitoring of community life and its services. It would comprehend community building and management of collective activities that "ultimately enable people to face problems of everyday life and constitute the basic fabric of day-to-day quality of life" (see [37], p. 24).

Management is becoming an integral part of investment activity in social housing. The managing work is performed by two people appointed by a property management company: the technical social advisor and the social manager. The engagements of the social manager include the presentation of services, management of financial and administrative aspects, but require noneconomic investments, typical for nonprofit and limited profit sectors. The main objective of the social manager is to provide high-quality services, including appropriate monitoring and evaluation, as well as the integration of economic and social dimensions. All activities of the social manager are performed with the goal of building and supporting social networks, stimulating participation in the community, and strengthening the sense of belonging [35-38].

Social housing interventions offer both public services for all citizens (local urban services) and semi-public services that are mainly addressed to the beneficiaries of the intervention (integral services to social housing). Local urban services support the opening up of new communities to local life while strengthening the relationships of the new intervention with the existing neighborhood. At the same time, they facilitate the integration of new inhabitants and consolidate social fabric. These services can be specialized for the user category or designed by merging complementary types of users (for example, the elderly and children). Services integral to social housing refer to collaborative residential spaces and activities that encourage a sense of belonging. Collective spaces (internal and external) and equipment of spaces are primarily intended for new residents. Through a process of constant sharing, the residents identify and structure all the activities whilst being guided by the social manager. During this process, people learn to collaborate with each other in order to find solutions for problems related to daily life, e.g., caring for children and buying food. Usually, alternative economic models are activated in this process. Even though social housing guarantees necessary spaces for living inside the house, the extension to the outdoor activities is strongly encouraged. Finally, 
all steps towards collaborative production of activities stimulate a new culture of living together: collaborative living.

\subsection{Social Housing Facilities of Different Sizes}

Congruent with the DP directions for possible physical modifications, we have selected three permitted types of intervention on the dilapidated buildings: demolition, demolition and reconstruction, and an increase in the number of floors of the building. An authorized demolition is possible if the buildings have no historical, aesthetic, or artistic significance. Economic viability usually prefers construction from scratch instead of a reconstruction. The space freed after the demolition can also maintain the configuration of open public spaces. Both demolition and reconstruction and an increase in the number of floors allow volume augmentation. However, the increase in volume must guarantee appropriate dimensions of housing units, adjusted to the lifestyle and type of beneficiaries.

The DP defines a possible increase in volume for each building. Another set of rules applies to the buildings of historical, aesthetic, or artistic values. The character of a singular building and its context conditions the interpolation rules. In some cases, according to the primary structure, restoration of the façade back to its original shape is obligatory. In some other circumstances, there is an obligation to align the façade with the surrounding buildings, e.g., in cases of row housing.

The 53 buildings out of a total of 95 dilapidated buildings are intended for demolition and reconstruction or an increase in the number of floors of the building. After being demolished, most of these 53 buildings are planned as new builds. The total amount of volumetric increase allows the construction of 15,000 cubic meters. This amount is a sum of new and existing volumes. We used this as a total volume for our calculation of the social housing intervention. The new builds in most of the social housing projects define the housing offer using size and shape measures, e.g., studio apartment, two-bedroom, or three-bedroom apartments. This is not possible in the case of Sassari because the project must reconstruct the existing built heritage. Nevertheless, it is still possible to calibrate the dimensions expressed in available cubic meters using the average size of the housing unit in the district.

The socio-demographic and legislation analysis permitted the distinction of five target groups of potential beneficiaries capable of initiating a regeneration process in the historic center of Sassari City:

- $\quad$ Single parent or single-income families;

- Low-income households (favoring young, low-income couples);

- Workers or student-workers (favoring those who work within the neighborhood);

- Offsite students;

- Regular, low-income migrants (favoring those already residing in the neighborhood or those who have family ties with the residents of the neighborhood).

The allocation of target groups does not identify the target group that will be the final user and what their needs are. The optimization of spatial requirements must maintain housing unit flexibility. Flexibility allows the evolvement of housing units over time as the users' needs change, including the concepts of adaptability and transformability. Adaptability implies the capability of a building or housing unit to support multiple functions without altering the architecture itself. Aimed at breaking the traditional distinction between activities that are performed exclusively inside or outside the house, the principle of adaptability simultaneously applies to apartments, buildings, and outdoor spaces. Transformability allows the interior or exterior space to be changed in response to certain stimuli without new construction. Some recipients of social housing are temporary since they receive benefits for a limited amount of time, e.g., in the case of offsite students or workers. Consequently, users shift constantly in and around this space. Likewise, the needs of the user may evolve over time, e.g., a young couple has a baby or a member of an elderly couple dies. Flexible spaces guarantee greater decision-making and organizational freedom. All of this results in the flexibility criterion being strongly encouraged in social housing design. 


\subsection{Nonresidential Spaces and Services Associated with the Social Housing}

\subsubsection{Open Spaces}

Urban open spaces can be open to all citizens and can be semi-private. Allowing casual or planned meetings of people, open public spaces are prerequisites for social cohesion. Fundamental to the newly formed communities, social cohesion is the basic quality of open public spaces. Public or semi-public open spaces ensure privileged places for exchanges and support the construction of identity. Semi-private open spaces have limited access as they allow the reserved gathering of social housing beneficiaries.

Due to the prescribed spatial patterns, future research will define precise positions to fit and upgrade the existing public space network.

\subsubsection{Collective Spaces and Activities}

Services integrated with social housing are semi-public services with a social character, primarily addressed to the beneficiaries and actors of social housing. They promote collective activities during the sharing process guided by the social manager. Furthermore, the collective use of spaces also has economic benefits. We have already argued that the concept of flexibility is fundamental to social housing interventions and this applies to the services as well. In the context of Sassari, social housing facilities are dispersed. The design of all necessary services in every single building or group of housing units would be uneconomical, if not impossible, to implement. The same thing applies to building all services into a few buildings.

In order to ensure multiple-uses, common areas require minimal equipment. Each common space must have at least one toilet, a kitchenette or a predisposition for it, and basic furnishings (tables, chairs, armchairs, shelves/furniture cabinets, and rubber carpets).

The spaces on the ground floor must have a greater degree of accessibility. They should host services that have concentrated and convivial use, such as gyms, spaces for courses, meetings, or events, spaces for free-time activities, including games, parties, or dinners, and small self-construction workshops.

Planning documentation allows the possibility of using rooftops as semi-private spaces, open or semi-open. The services located on the rooftops are more easily accessible to residents of housing facilities because they are necessarily located within the same building, but the services have to be open to all actors of social housing. They are more intimate and peaceful spaces that are suitable for hosting services such as shared kitchens or activities such as study or work. They can be designed as green spaces or also self-constructed by inhabitants.

\subsubsection{Local Urban Services}

Local urban services are public and serve all citizens. Local urban services have to supply the cumulative needs of the local community, aimed at strengthening the links between the new intervention and the existing neighborhood context. The links activate through social networks among beneficiaries and their relations to the neighborhood and district. Local urban services can be designed for specific or intersected needs. They have to increase well-being within the community, but may also attract external population.

The historic center of Sassari demonstrates a variety of socio-demographic contexts and, possibly, a high diversity of new inhabitants, mentioned as beneficiaries of the social housing intervention. The range of services that can be activated is quite extensive. For this reason, we decided to proceed with categories of the possible services rather than listing a singular function that they should perform. Five categories of local services are identified as follows: commercial activities (local and general), co-working spaces and study rooms, catering businesses, cultural and leisure activities, and municipal services. Furthermore, we propose three basic requirements for the design of local services within the neighborhood: accessibility, flexibility, and strategic distribution. The selected requirements contribute to strengthening the links between local services and public spaces. 
"Design for all" (a design that suits various groups of people) is necessary for social housing intervention because the recipients are fragile groups of people. All people must have the possibility of access to the services. At the same time, the urban design activates and facilitates social protection and regeneration in the context of the historical center. Despite the fact that the buildings and public spaces are degraded, and the level of accessibility is low, the adaptation of these spaces to maximize accessibility criteria matters in the case of new builds.

The flexibility of local services primarily refers to functional variety and multi-functional use at the same time. Additionally, the spatial composition and equipment have to be flexible; transformability follows adaptability. The more diverse the community is, the more flexibility is required of the spaces.

The strategic distribution of local services is the key objective because of the specific morphological characteristics and uneven distribution of social and housing issues across the historical center of Sassari. The spatial-morphological characteristics of the available housing stock require dispersed planning. A simultaneous prevalence of economic activities conflicts with the absence of essential and specialized services for daily life. Therefore, the design of new local services should ensure an even distribution per district. Dispersion of services could prevent further inequities if a larger number of people from diverse neighborhoods use them intensively.

\section{Instead of Conclusions}

This paper is based on ongoing research about social housing intervention in the historic center of Sassari. In the national and regional context, social housing is an important and developing topic even though housing affordability has already affected the growing population for a few decades. Sardinian territory urgently needs integral social housing projects, even though proposals are scarce. We took this situation as an opportunity; however, the government does not recognize social housing needs or potential. We can only conclude that numerous negotiations are needed to implement the social housing model, and further work is needed to make it a common practice. This is coherent with the practice of European cities, which urge that replicable models require support from higher levels of governance $[4,5]$. We might have the support of the local municipality, but the difficulties that may appear are linked to vertical politics. In addition, local officials are not familiar with the governance of cohesion politics and might not have the capacity to implement the integral approach to social housing. Although the planning practice of Sassari does not function on multiple scales, this situation is challenging. The change of planning practice may sound too ambitious, but we recognize the support from local governments as a great starting point.

Another challenge to overcome is the integration of new inhabitants within the existing neighborhood in the presence of socio-spatial segregation. This implies co-designing within each of five districts in the historic center because the socio-demographic structure may differ significantly from district to district. On the other hand, investment in the presently scarce services might be the opportunity for strengthening the relationships within the districts if the service guarantees the intersecting interests between social housing beneficiaries and the existing local community. In the next phase, we plan to develop possible relationships between the type and functions of housing units. We expect that collaborative and local urban services may collide. Further research will develop possibilities for a functional extension of activities to the outdoors. The public space network will be integral to the social housing model.

The integral approach to social housing and the concept of collaborative community is not an innovation of this paper, but an emerging practice in the national context and an unfamiliar practice in Sardinia. The approach is based on context-specificities, yet this does not limit its replicability potential. The components of the social housing model can be applied to similar contexts of historical centers or any other urban area in decay. The outputs will vary due to the abandoned housing stock and spaces and community profiles.

The distinctive and innovative aspect of our approach is the dispersed social housing that emerged from the choice to intervene in the existing building heritage. Implementation of such intervention 
requires greater attention on accessibility, design for all, and maximum possible flexibility in the design of buildings, spaces, and functions. This question is going to be further investigated. The choice to intervene in the existing building heritage also brings up technical matters. We were forced to argue using the housing unit expressed in cubic meters and not by the type of unit, which is the traditional way used in the previous studies. This is a technical and administrative obstacle to overcome.

Important challenges may appear from this first discussion. For example, within the historic center of Sassari resides a range of people with foreign origin. What can a flexible place for a community composed of such a variety of cultural backgrounds mean?

\section{Directions for Future Research}

More research is needed to complete the proposal of the social housing model, followed by governance scenarios. Research to come will define supporting aspects of the social housing project, which include legislative and administrative mechanisms. We will adjust the model to the purchasing capacity of the interested population and possibilities for new public-private investment patterns. The economic feasibility of the selected area will enclose the project proposal. Hopefully, in the future, the research project will be extended to ensure the realization of a pilot project.

Author Contributions: Conceptualization, N.B.; methodology, V.T. and N.B.; formal analysis, N.B. and V.T.; investigation, V.T. and N.B.; data curation, V.T.; resources, N.B. and V.T.; writing - original draft preparation, N.B.; writing-review and editing, N.B. and V.T.; visualization, N.B.; supervision, V.T.; project administration, V.T.; funding acquisition, V.T. All authors have read and agreed to the published version of the manuscript.

Funding: The APC was funded by the research project "Disegno e valutazione di politiche e progetti per la rigenerazione urbana di quartieri interessati da fenomeni di spopolamento e marginalità socio-spaziale attraverso interventi basati sul welfare abiatativo" ("Design and evaluation of the politics and projects of urban regeneration through interventions based on housing walfare. This applies in the areas affected by depopulation and socio-spatial marginality"). Funded by Fondazione di Sardegna (budget of the year 2016 for research projects with peer review, based on the financial resources provided by Fondazione di Sardegna) and co-financed with Legge Regionale 7 /2007 for the year 2016.

Acknowledgments: We acknowledge the technical support by Nicola Solinas for the GIS data elaboration.

Conflicts of Interest: The authors declare no conflict of interest. The funders had no role in the design of the study; in the collection, analyses, or interpretation of data; in the writing of the manuscript, or in the decision to publish the results.

\section{References}

1. Musterd, S.; Ostendorf, W. Integrated urban renewal in The Netherlands: A critical appraisal. Urban Res. Pract. 2008, 1, 78-92. [CrossRef]

2. Couch, C.; Fraser, C. Introduction. In Urban Regeneration in Europe, 1st ed.; Couch, C., Fraser, C., Percy, S., Eds.; Blackwell Science Ltd: Oxford, UK, 2003; pp. 1-16.

3. Czischke, D.; Moloney, C.; Turcu, C. State of the Art on Sustainable Regeneration in Urban Areas; URBACT II capitalisation, December 2014; URBACT: Saint Denis, France, 2015.

4. Colantonio, A.; Dixon, T. Urban Regeneration \& Social Sustainability. In Best practice from European Cities, 1st ed.; Wiley Blackwell: West Sussex, UK, 2011.

5. Ramsden, P.; Colini, L. Urban Development in the EU: 50 Projects Supported by the European Regional Development Fund During the 2007-13 Period; Draft Final Report; European Union: Brussels, Belgium, 2013; Available online: https://ec.europa.eu/regional_policy/sources/docgener/studies/pdf/50_projects/urban_dev_erdf50.pdf (accessed on 1 April 2020).

6. Chaline, C.; Coccossis, H. Guidelines for Urban Regeneration in the Mediterranean Region; Priority Actions Programme Regional Activity Centre Split: Split, Croatia, 2004; Available online: https://www.papthecoastcentre.org/pdfs/Urban\%20Regeneration.pdf (accessed on 2 April 2020).

7. Roberts, P. The Evolution, Definition and Purpose of Urban Regeneration. In Urban Regeneration: A Handbook, 1st ed.; Roberts, P., Sykes, H., Eds.; Sage: London, UK, 2000; pp. 9-36.

8. Bromley, R.; Tallon, A.; Thomas, C. City Centre Regeneration through Residential Development: Contributing to Sustainability. Urban Stud. 2005, 42, 2407-2429. [CrossRef] 
9. Lalović, K.; Živković, J.; Radosavljavić, U.; Đukanović, Z. An Integral Approach to the Modeling of Information Support for Local Sustainable Development-Experiences of a Serbian Enabling Leadership Experiment. Sustainability 2019, 11, 2675. [CrossRef]

10. Olagnero, M.; Ponzo, I. Promoting Social Mix through Tenure Mix: Social Housing and Mega-Event Regeneration. In Turin, In Social Housing and Urban Renewal (A Cross-National Perspective); Watt, P., Smiths, P., Eds.; Emerald Publishing Limited.: Bingley, UK, 2017; pp. 179-213. [CrossRef]

11. Bolt, G.; Phillips, D.; Kempen, R.V. Housing Policy, (De)segregation and Social Mixing: An International Perspective. Hous. Stud. 2010, 25, 129-135. [CrossRef]

12. Keresztély, K. Urban Renewal as a Challenge for European Urban Development in the 21st Century. Cities. Territories. Governance. 2016. Available online: http://www.citego.org/bdf_fiche-document-532_en. html\#iref:note (accessed on 2 April 2020).

13. Turcu, C. Local experiences of urban sustainability: Researching Housing Market Renewal interventions in three English neighbourhoods. Prog. Plann. 2012, 78, 101-150. [CrossRef]

14. Tanrikul, A.; Hoşkara, Ş. A New Framework for the Regeneration Process of Mediterranean Historic City Centres. Sustainability 2019, 11, 4483. [CrossRef]

15. Lang, T. Socio-Economic Regeneration outside of Agglomerations-Local Economic Development in the Baltic Sea Region. Theoretical background. In Small and Medium-Sized Cities in the Baltic Sea Region.Socio-Economic and Cultural Approaches to Urban Development, 1st ed.; Lang, T., Sonntag, M., Tenz, E., Eds.; Edition Kirchhof \& Franke: Leipzig, Germany, 2005; pp. 20-31.

16. El Menchawy, A. Urban Regeneration in Mediterranean Cities: An Integrated Urban Development of Brownfield Sites. WIT Trans. Ecol. Environ. 2008, 117, 115-127.

17. Relazione Annuale di Banca di Italia sul 2014, Pubblicata il 21 Maggio 2015; Annual rapport 2014; Bank of Italy: Rome, Italy, 2015; Available online: https://www.bancaditalia.it/pubblicazioni/relazione-annuale/2014/ appendice_2014_completa.pdf (accessed on 19 December 2019).

18. Società italiana di iniziative edilizie e fondiarie-SIDIEF (Italian Society of Housing and Land-use Initiatives). In Proceedings of the Investire sulla casa. Politiche e strumenti per l'affitto in Europa, Proposte per l'Italia (Investing in the house. Rental politics and instruments in Europe), Rome, Italy, 20 May 2015.

19. Tosi, A. Abitanti: Le Nuove Strategie Dell'azione Abitativa (Inhabitants: The New Housing Strategies); Il Mulino: Bologna, Italy, 1994.

20. Pittini, A. The State of Housing in the EU 2019; Housing Europe, the European Federation of Public, Cooperative and Social Housing: Brussels, Belgium, 2019.

21. Czischke, D.; Pittini, A. Housing Europe 2007. Review of Social, Co-Operative and Public Housing in the 27 EU Member States; CECODHAS European Social Housing Observatory: Brussels, Belgium, 2007.

22. Direzione Affari Economici e Centro Studi Associazione Nazionale Costruttori Edili-ANCE. Osservatorio Congiunturale Sull'industria delle Costruzioni; (National Association of Building Constructors, Economic Affairs Direction and Study Center. Contingent observatory on the construction industry); Edilistampa: Roma, Italy, 2014.

23. Statistics by the Bank of Italy. Available online: https:/www.bancaditalia.it/statistiche/index.html (accessed on 14 April 2020).

24. Fregolent, L.; Torri, R. L'Italia senza casa. In Bisogni emergenti e politiche per l'abitare (Italy without Home. Emerging Needs and Housing Politics), 1st ed.; Franco Angeli: Milano, Italy, 2018.

25. Osservatorio del Mercato Immobiliare and Associazione Bancaria Italiana. Rapporto Immobiliare 2015: Il settore residenziale (Real Estate Market Observatory and Italian Banking Association. In Annual rapport 2015: The Residential Sector; 2015. Available online: https://www.agenziaentrate.gov.it/portale/documents/ 20143/263246/rapporto+immobiliare+2015_RI_2015_QuadroGenerale_21052015.pdf/ae4b1ead-5a15-37cf156f-6832e027778d (accessed on 19 December 2019).

26. Cassa Depositi e Prestiti S.p.A. (Deposits and Loans Fund). Social Housing. Il mercato immobiliare in Italia: Focus sull'edilizia sociale (Social housing. The Real Estate Market in Italy: Focus on Social Housing); Cassa depositi e prestiti S.p.A.: Roma, Italy, 2014.

27. Ferri, G.; Pacucci, L. Realizzare Housing Sociale. Promemoria per chi Progetta (Social Housing Realization. Reminder for Designers), 1st ed.; Bruno Mondadori Edizioni: Milano, Italy, 2015.

28. Ministry of Infrastructure, Decree published on 22 of April 2008. Available online: https://www. amministrazionicomunali.it/docs/pdf/DM_3904_2008.pdf (accessed on 24 March 2020). 
29. House Plan Decree-Law 112/ 2008 Art.11. Available online: https://www.gazzettaufficiale.it/eli/id/2008/08/21/ 08A05897/sg (accessed on 24 March 2020).

30. Ministerial Decree, 24 of February 2015. Available online: https:/www.gazzettaufficiale.it/atto/serie_generale/ caricaDettaglioAtto/originario?atto.dataPubblicazioneGazzetta=2015-05-20\&atto.codiceRedazionale= 15A03684 (accessed on 23 March 2020).

31. Italian Statistical Institute-ISTAT. $15^{\circ}$ Censimento della Popolazione e delle Abitazioni 2011 (Population and Housing Census 2011). Available online: https://www.istat.it/it/censimenti-permanenti/censimentiprecedenti/popolazione-e-abitazioni/popolazione-2011 (accessed on 19 December 2019).

32. Piano Urbanistico Comunale-PUC (Municipal Urban Plan). Available online: http://www.comune.sassari. it/comune/puc/puc_indice_new_doc.html (accessed on 9 April 2020).

33. Piano Particolareggiato Centro Storico (Detailed Plan of the Historical Center). Available online: http://www. comune.sassari.it/comune/amministrazione_trasparente/pianificazione.htm (accessed on 9 April 2020).

34. Centro Elaborazione Dati del Comune di Sassari-CED; Municipal Data Processing Center, Sassari, Italy. Personal Communication, 2019.

35. Bua, F.; Idini, P.; Talu, V. Sassari: Una città da "ricomporre". Il centro storico come laboratorio di politiche e progetti di rigenerazione urbana centrati sugli abitanti (Sassari: A city to "recompose". The historical center seen as a laboratory of policies and urban regeneration projects that centralize the inhabitants). In Sardegna. La nuova e l'antica felicità (Sardinia. The New and the Old Happiness); Franco Angeli: Milano, Italy, 2013; pp. 97-127.

36. Elnokaly, A.; Elseragy, A. Sustainable Urban Regeneration of Historic City Centres-Lessons Learnt. In Proceedings of the World Sustainable Building Conference, Helsinki, Finland, 21 October 2011; Available online: https://pdfs.semanticscholar.org/db78/decfd4aaafc7703e98122553bef741df820f.pdf?_ga=2.134974962. 2063831871.1586348779-1046350870.1582142009 (accessed on 25 March 2020).

37. Manzini, E. Design, When Everybody Designs. An Introduction to Design for Social Innovation; Coad, R., Ed.; MIT Press: Cambridge, MA, USA, 2015.

38. Ferri, G. Starting Up Communities. In Un Design-kit per l'abitare Collaborativo, 1st ed.; Bruno Mondadori Edizioni: Milano, Italy, 2016.

(C) 2020 by the authors. Licensee MDPI, Basel, Switzerland. This article is an open access article distributed under the terms and conditions of the Creative Commons Attribution (CC BY) license (http://creativecommons.org/licenses/by/4.0/). 